\title{
Making Hay out of Straw? \\ Real and Imagined Controversies in Evolutionary Psychology
}

Robert Kurzban \& Martie G. Haselton

University of California Los Angeles

Revised Draft: 12/19/2001

Correspondence regarding this manuscript should be sent to:

Robert Kurzban

Department of Psychology University of Pennsylvania

3815 Walnut St.

Philadelphia, PA, 19104-6196

U. S. A.

kurzban@psych.upenn.edu 


\section{Making Hay out of Straw?}

Real and Imagined Controversies in Evolutionary Psychology

As evolutionary psychology has risen in popularity, it has attracted its share of detractors. Some critics have raised important issues that will ultimately require empirical testing to resolve. Others have attacked strawmen: views inaccurately attributed to leading scholars in the field. In this chapter, we address both types of criticisms in an attempt to steer the debate in productive directions.

\section{Strawmen}

Genetic Determinism. The doctrine of genetic determinism holds that the behavior of organisms depends in no way on the environment; the organism's genes wholly determine the organism's behavior. In the realm of evolutionary psychology, this is often portrayed as the belief that human brains are "hard-wired," developing in particular ways independent of the environment in which they mature.

Do critics portray evolutionary psychology as genetically deterministic? Nelkin (2000) says "Evolutionary principles imply genetic destiny. They de-emphasize the influence of social circumstances" (p. 27). Herrnstein Smith (2000) echoes this remark, claiming that evolutionary psychologists "dismiss" cultural, historical and individual variables (p. 167), singling out Pinker's supposed claims of human sexuality's “definitive determination (in presumably all senses)" (p. 171) and immunity from social influences. Shakespeare and Erikson (2000) agree, suggesting that "[i]n these [evolutionary] approaches it is possession of a specific set of genes, or a particular configuration of a hard-wired brain, constituted via evolutionary mechanisms, which explains any given social phenomenon" (p. 231). Karmiloff-Smith (2000) also cautions that, in contrast to the 
evolutionary view, “...behaviors are not simply triggered from genetically determined mechanisms" (p. 174), and later, that evolutionary psychologists should consider the developing organism's myriad interactions with the environment in contrast to "their onesided approach" (p. 184).

More generally, critics equate biology with fixedness. H. Rose (2000) refers to "biological imperatives" and "biology-as-destiny" (p. 149), while Jencks (2000) talks about "built-in genetic program(s)...hard-wired into our brains by natural selection..." (p. 34). Fausto-Sterling (2000) is skeptical about evolutionary psychology's "hard-wired view of the inflexibility of social arrangements..." (p. 221).

Compare the positions attributed to evolutionary psychologists with the published views of evolutionary psychologists on this topic:

“...every feature of every phenotype is fully and equally codetermined by the interaction of the organism's genes ... and its ontogenetic environments..." (Tooby and Cosmides, 1992, p. 83)

“...every part of every organism emerges only via interactions among genes, gene products, and myriad environmental phenomena..." (Symons, 1992, p. 140) “...every part of human intelligence involves culture and learning..." (Pinker, 1997, p. 33) “...it is a complete misconception to think that an adaptationist perspective denies or in the least minimizes the role of the environment in human development, psychology, behavior, or social life..." (Tooby and Cosmides, 1992, p. 87) 
Evolutionary psychologists do not merely acknowledge the undeniable influences of the environment - many of their research programs have focused on the specifics of how people respond contingently to its features. Belsky, Steinberg, and Draper (1991), for instance, proposed that one potentially important aspect of a maturing woman's environment is whether her father is present or absent. Their evolutionary model predicted that a father's absence would cause a woman to become sexually mature earlier, and be less restrictive in her sexual behavior. Drawing on this model, Ellis and colleagues demonstrated that father absence and family stress predicted early pubertal timing in girls (Ellis \& Garber, 2000; Ellis et al., 1999). Other evolutionary psychologists have tested evolutionary hypotheses about contingent sexual strategies in men (Gangestad \& Simpson, 2000).

In similar fashion, Sulloway (1996) suggested that differences among children's personalities within a family might reflect evolved strategies contingent on birth order. He predicted and found that early-born children, who have enjoyed a monopoly on parental attention, tended to be conservative and adhere to parental authority, while later-borns rebelled against the authority of dominant social institutions. Sulloway is one of many evolutionary psychologists whose theories of environmentally-sensitive evolved strategies have driven empirical research programs (e.g., Hill \& Hurtado, 1996; Hill, Ross, \& Low, 1997; Malamuth, 1998; Pedersen, 1991).

Cross-Societal Variation. Critics who assume either explicitly or implicitly that biological approaches imply behavioral fixity infer that societal variation presents a problem for evolutionary psychology. Two recent articles critical of Buss's (1989) 
evolutionary hypotheses about sex differences in mate preferences are illustrative. At issue was Buss's finding that, relative to women, men across 37 geographic regions spanning 6 continents and 5 islands placed a greater emphasis on physical attractiveness in a mate, whereas women placed a greater emphasis on ambition, status, and access to resources (Buss, 1989).

Based on social structural theory (Eagly, 1987) and related accounts, Eagly and Wood (1999) proposed that women's preferences for mates with access to resources might be driven cross-societally by institutions that varied in the extent to which women were permitted to acquire resources. To test this hypothesis, Eagly and Wood correlated measures of gender inequity with mate preferences measured by Buss (1989). Kasser and Sharma (1999) conducted a similar analysis using measures of gender disparity in educational access and reproductive rights.

In both studies, the authors found that these measures predicted the size of the sex differences in some of the mate preferences they investigated. By contrasting evolutionary and social structural hypotheses, the authors implied that patterned cross-societal variation predicted by the social structural accounts weakened evolutionary accounts of sex differences in mate preferences. Kasser and Sharma (1999) suggested that their findings were "counter to the strong evolutionary position that culture has a negligible effect on females' mate preferences." They further explained that "a more parsimonious explanation can be made without recourse to evolutionary mechanisms" (p. 376). In their title, "Evolved dispositions versus social roles," Eagly and Wood (1999) intimated that support for social roles hypotheses called into question evolutionary theorizing - which, by their 
rendering, entails "claims of invariance across cultures in sex-differentiated behavior" ( $\mathrm{p}$. 420).

These conclusions hinge critically on the idea that societal variability predictions flow from social structural accounts but not from evolutionary accounts. However, evolutionary psychologists contend that adaptations are structured to respond contingently to local social and ecological factors (see Cronk, this volume). For example, in 1989, evolutionist Bobbi Low proposed that natural selection might have shaped parental socialization of boys and girls to respond contingently to variation in 1) the prevalence of polygyny and 2) sex differences in resource control. This account successfully predicted that parents across societies would alter their child rearing practices to encourage female achievement and aggression as female control of resources increased (Low, 1989), a prediction similar to that advanced by Eagly \& Wood (1999).

An additional example of this type of reasoning is Gangestad and Buss' (1993) evolutionary hypothesis regarding variation in preferences for physical attractiveness across different societies. Gangestad and Buss proposed that the emphasis men and women place on physical attractiveness in a mate might be partially explained by parasite prevalence. Over the course of human evolution, the number of parasites in the environment probably varied from place to place. Individuals' resistance to parasites would therefore be more important in some places than in others. Gangestad and Buss suggested that because physical attractiveness is in part a function of parasite resistance, mate preference mechanisms have evolved to place more weight on attractiveness as a mate selection criterion as parasite prevalence increases. Gangestad and Buss supported this prediction in an analysis of mate preferences across 37 geographical regions. They 
demonstrated a positive association between parasite prevalence and the emphasis individuals place on physical attractiveness within a society (Gangestad \& Buss, 1993).

Many evolutionary psychologists endorse the view that there is a universal human nature. However, universal psychological mechanisms can and do generate variable behavior as a result of their design to respond adaptively to environmental circumstances (Barkow, 1989; Tooby \& Cosmides, 1990). In fact, as Barkow (1989) has pointed out, given the broad range of environments humans were likely to have experienced over evolutionary history, a rigid and unresponsive psychology would constitute an exceptionally poor design.

In short, cross-societal variation itself does not present a problem for evolutionary psychology. The only way in which societal variability challenges evolutionary psychologists is the same way it challenges all social scientists: its likely causes are many and complex, making hypothesis formulation and testing a formidable (but not impossible) task.

Hyperadaptationsim. Evolutionary psychology is often portrayed as overly adaptationist, endorsing the idea that all features of organisms are adaptations. This view is contrasted with the more "pluralistic" view, which Gould has emphasized throughout his long and prolific career, that not all features of organisms are adaptations, but that there are also epiphenomenal by-products of other adaptations, and contingently historical artifacts that were adaptations in ancestral species, but are no longer (e.g., Gould, 1997). Gould criticizes evolutionary psychologists for failing to recognize this, suggesting that the "internal error of adaptationism arises from a failure to recognize that even the strictest operation of pure natural selection builds organisms full of nonadaptive parts and 
behaviors" (p. 123). Gould is not the only one to make such claims. S. Rose (2000), for example, characterized the field this way: "every feature of the phenotype, from the protein structures within its cells to its behavioral responses to environmental contingencies, must be considered as adaptations" (p. 302 - 303).

It is very difficult to understand how critics come to attribute hyperadaptationism to evolutionary psychologists, as they endorse Gould's pluralism explicitly and frequently. Here are some representative examples:

"In addition to adaptations, the evolutionary process commonly produces two other outcomes visible in the designs of organisms: (1) concomitants or by-products of adaptations (recently nicknamed "spandrels"; Gould \& Lewontin, 1979); and (2) random effects.” (Tooby \& Cosmides, 1992, p. 62)

"Organisms can be understood only as interactions among adaptations, byproducts of adaptations, and noise..." (Pinker, 1998, p. 174). “...the evolutionary process produces three products: naturally selected features (adaptations), by-products of naturally selected features, and a residue of noise" (Buss et al., 1998, p. 537).

Other evolutionary psychologists have made similar statements (see Dennett, 1995, p. 537; Daly and Wilson, 1988, p. 12). Not only do evolutionary psychologists acknowledge the existence of by-products and noise, they explicitly test by-product hypotheses (e.g., Kurzban, Tooby, \& Cosmides, 2001; Cosmides \& Tooby, 1992). In addition, they acknowledge that adaptationist claims must be backed by evidence: "To show that an organism has cognitive procedures that are adaptations... One must also 
show that their design features are not more parsimoniously explained as by-products..." (Cosmides \& Tooby, 1992, p. 180).

Ironically, in the same volume of essays in which Gould and Rose's comments appear, Fausto-Sterling makes exactly the reverse criticism. She takes issue with Don Symons' (1979) speculation that the female orgasm might be a by-product rather than an adaptation (Fausto-Sterling, 2000, p. 211), existing only because of the male orgasm, with the design "carried over" to the other sex. Whichever view proves to be correct, FaustoSterling here seems guilty of precisely the sins of which evolutionary psychologists stand accused, while Symons is as pluralistic as Gould could ask.

Gould (2000) has also recently questioned whether adaptation need be invoked for understanding why human males invest in their offspring. His explanation is this: "A man may feel love for a baby because the infant looks so darling and dependent and because a father sees a bit of himself in his progeny. This feeling need not arise as a specifically selected Darwinian adaptation...” (p. 122).

Interestingly, in a very entertaining piece twenty years earlier, Gould (1979) showed how Disney’s Mickey Mouse takes advantage of humans' preferences for neotenous features, changing over the course of his own evolution from his slightly shady start in "Steamboat Willie" to the modern, more neotenous Mickey Mouse. In Gould's own words: "When we see a living creature with babyish features, we feel an automatic surge of disarming tenderness. The adaptive value of this response can scarcely be questioned, for we must nurture our babies" (Gould, 1979, p. 33).

For Gould, the human preference for neoteny is adaptive (1979), yet not necessarily an adaptation (2000). And if not adaptation, the only alternative is a spandrel, 
or by-product. Gould's suggestion, then, is that parental love for babies is an accident, mere happenstance—a phenomenally improbable and obviously lucky state of affairs. If this claim were made of any other species, we doubt the idea would be entertained for a moment: is it possible that penguin dads care for penguin chicks by accident, rather than design?

In this chapter we are not attempting to elaborate evidence for parental investment adaptations in human males. Our point is simply that peoples' requirements differ in terms of how unlikely complex functional design must be before the case for adaptation is made. Stephen J. Gould (2000) is as skeptical as one could ask of a scientist, allowing for the possibility of unfathomably unlikely scenarios.

Controversies Surrounding the Application of Evolutionary Biology to Human Psychology

Steven Pinker (1998) used the example of an olive-pitter to discuss the value of considering design. Imagine what critics of evolutionary approaches might say were someone to come across an olive pitter and speculate that it was good at pitting olives because it was designed to do so. Gould might claim that this was an unfounded and possibly unfalsifiable "Just So" story, emphasizing that there was no evidence of the history of the artifact, as nothing whatsoever was known about the factory in which it was produced. Others would claim that a more "parsimonious" explanation would be that it was good at pitting olives because it had a little plunger mechanism here, a sharp point there, and so forth. Finally, as discussed above, they might claim that it could very well be that the olive pitter is an incidental by-product, the left-over material from a factory that makes, for example, sewing machines. This particular by-product, it would be argued, just happens to be good at pitting olives. 
These arguments, insufficient historical data, the sovereign status of proximate explanations, and by-product hypotheses, are common criticisms of evolutionary psychology.

Gould asks: “...how can we possibly obtain the key information that would be required to show the validity of adaptive tales about the EEA... We do not even know the original environment of our ancestors..." (p. 120). Note that for Gould this information seems to be a requirement to show design. Benton (2000) is similarly concerned about the "fragmentary sources of evidence available from the fossil record" (p. 262), and FaustoSterling (2000) suggests that because we know so little about the ancestral past, "evaluating competing hypotheses becomes very difficult" (p. 214). Gould concludes that “...the key strategy proposed by evolutionary psychologists for identifying adaptation is untestable and therefore unscientific" (Gould, 2000, p. 120).

Evolutionary psychologists do indeed use what is believed to be true of our species' evolutionary history to generate hypotheses. However, developing evidence of adaptation does not require precise knowledge of the history of selection because evidence of adaptation in evolutionary psychology is exactly the same as it is in evolutionary biology: evidence of special design. A hypothesis about design should lead to testable predictions (for extended discussions of this issue, see Buss et al., 1998; Holcomb, 1998; Ketelaar \& Ellis, 2000). The question is not whether we can know for certain what our ancestral past was like. The question is whether or not we can use what we do know about ancestral environments to develop new hypotheses (Barkow, 1989). Consider that with each feature of the olive pitter the chef demonstrated, each exquisitely tuned to its 
function, an observer would become increasingly convinced as to its purpose, knowing nothing at all about the artifact's history.

Does a description of the mechanics of the olive pitter replace an explanation in terms of its design? S. Rose suggests that evolutionary psychologists "insist on distal (in their slightly archaic language, "ultimate") explanations when proximate ones are so much more explanatory...” (p. 3), and again later, that “...proximal mechanisms...are much more evidence-based as determining levels of causation, should these be required, than evolutionary speculations." (p. 305; for similar claims, see H. Rose (2000), p 146 and S. Rose (2000), p. 313).

Humans, like artifacts, have parts, and these parts have functions. It seems reasonable to derive hypotheses about these functions from the standpoint of design. We do not wish to suggest that alternative approaches for hypothesis development-reliance on observation, intuition, or guesswork — are any less legitimate. However, providing a proximal explanation neither invalidates an ultimate explanation nor replaces it. This is analogous to showing the mechanics by which an olive pitter pits and claiming that it is therefore not designed to perform this function. Anything that is designed to accomplish a task must be instantiated physically in the world. Whether a mechanism is an artifact or organic, and regardless of its function, it is possible to describe its operation in physical, proximate terms.

The claim that evolutionary psychologists "insist on distal" explanations is mostly true, but misleading. It is misleading in that the implication is that evolutionary psychologists insist on only distal explanations, to the exclusion of proximate explanations. While most psychologists are content to think only about proximate causation, 
evolutionary psychologists are interested in multiple levels of analysis. We consider multilevel investigations a strength in the field, not a flaw.

The Real Debate: Domain Specificity

There are areas of debate in which there are genuinely different points of view. Some of these debates are between evolutionary psychologists and those who endorse alternative non-evolutionary hypotheses (e.g., Buss, Larsen, Semmelroth \& Westen, 1992; Harris, 2000), while other debates take place within the field, among practitioners. Disagreements can take place on logical grounds (e.g., Pinker, 1998 vs. Fodor, 2000), differing interpretations of existing data (e.g., Buss \& Duntley, 2000 vs. Daly \& Wilson, 1988), or, the largest category, as yet unknown answers to questions that will ultimately be decided empirically.

The single most critical arena of legitimate debate in evolutionary psychology is the extent to which the human mind is "modular" or "domain specific." These terms are used differently by different authors, but very generally, modularity refers to the extent to which the mind consists of a large number of very functionally specific and relatively isolated information-processing devices as opposed to a smaller number of more general systems. Another way to put this is to ask how many mental "organs" there are, and the extent to which the organs themselves are composed of specialized subsystems.

Most evolutionary psychologists favor some variation of the view that the mind is likely to possesses many functionally distinct mental organs, with some anchoring each pole of a continuum from extreme (Sperber, 1994) to modest (Mithin, 1996) modularity. This debate ranges across disciplines, discussed by philosophers, neuroscientists, psychologists, and anthropologists. Recently, Pinker's (1998) How the Mind Works 
defended a modular view, challenged by Fodor's (2000) cleverly titled The Mind Doesn't Work That Way.

The critical point is that challenges to domain specific hypotheses in the form of hypotheses about more general mechanisms are thoroughly legitimate. In fact, these challenges are welcome alternatives to arguments centering on the false dichotomies of the past: biological versus cultural, innate versus learned, genetic versus environmental. Any given psychological mechanism can be more or less domain specific, but all mechanisms must result from an interaction of genes and environment. As discussed above, it is on this latter point that all reasonable parties agree, despite protestations of the critics to the contrary.

Challenges to domain specific hypotheses have spawned productive debates. The question of whether face recognition is performed by a mechanism specialized for this task is one example, and here progress has been made, with experimental and neuropsychological evidence in favor of the domain specific view accumulating (Kanwisher, 2000). Certainly the debate surrounding the question of the specificity of language learning has been a fruitful one (Pinker, 1984), as has the controversy surrounding specificity in the mechanisms underpinning children's acquisition of knowledge in the areas of biology, folk psychology, and physics (Hirschfeld \& Gelman, 1994).

Nowhere is this debate more vivid than in discussions of culture. Ideas, norms, and rules that differ between societies are all acquired by some kind of learning mechanism. In the case of religion, for example, Boyer (2001) has shown that the religious ideas observed across societies share certain important properties. He argues that because 
domain specific mechanisms generate religious ideas out of an alphabet of possible components, certain ideas - such as a deity that exists only on Wednesdays - do not arise or get widely transmitted. In contrast, ideas about entities that violate intuitive ontologies - such as artifacts with human-like qualities - continuously appear in religious traditions. Other researchers have similarly addressed transmission of cultural ideas, postulating various degrees of specificity (e.g., Barkow, 1989; Boyd \& Richerson, 1985).

\section{Conclusion}

In summary, debates should move past mischaracterizations and toward a discussion of genuine issues of contention. In order for fruitful debates to occur, all parties will need to agree that evolutionary psychologists argue the following:

1) The environment is extremely important to any organism's development.

2) Organisms have parts that are not adaptations, but by-products or noise.

3) Hypotheses that do not yield new insights are not useful.

4) There are multiple levels of explanation for any given phenomenon.

5) Claims for adaptation require support, usually in the form of evidence of special design.

There is no guarantee of course that any particular piece of evolutionary psychology will conform to these ideals. However, we are optimistic that debates that transcend the common misattributions and move to an earnest discussion of core issues of contention will result in far greater understanding of the human mind and behavior. Author Note: We thank Jerry Barkow, Clark Barrett, and April Bleske for helpful comments on earlier drafts of this chapter. 


\section{References}

Barkow, J. J. (1989). Darwin, sex, and status: Biological approaches to mind and culture. Toronto: University of Toronto Press.

Belsky, J., Steinberg, L., Draper, P. (1991). Childhood experience, interpersonal development, and reproductive strategy: An evolutionary theory of socialization. Child Development, 4, 647-670.

Benton, T. (2000). Social causes and natural relations. In H. Rose \& S. Rose (Eds.) Alas poor Darwin: Arguments against evolutionary psychology (pp. 249-270). New York: Harmony Books.

Boyd, R., \& Richerson, P. J. (1985). Culture and the evolutionary process. Chicago: University of Chicago Press.

Boyer, P. (2001). Religion explained: The evolutionary origins of religious thought. New York: Basic Books.

Buss, D. (1989). Sex differences in human mate preferences: Evolutionary hypotheses tested in 37 cultures. Behavioral and Brain Sciences, 12, 1-49.

Buss, D. M. \& Duntley, J. D. (2000). The killers among us: A co-evolutionary theory of homicide. Paper presented to the Annual Meeting of the Human Behavior and Evolution Society, Amherst, MA. June 8.

Buss, D. M, Haselton, M. G., Shackelford, T. K. Bleske, A. L., \& Wakefield, J. C. (1998). Adaptations, exaptation, and spandrels. American Psychologist, 53, 533-548.

Buss, D. M., Larsen, R. J., Westen, D., Semmelroth, J. (1992). Sex differences in jealousy: Evolution, physiology, and psychology. Psychological Science, 4, 251-255 
Cosmides, L., \& Tooby, J. (1992). Cognitive adaptations for social exchange. In J. Barkow, L. Cosmides, \& J. Tooby (Eds.), The adapted mind (pp. 163-228). New York: Oxford University Press.

Daly, M. \& Wilson, M. (1988). Homicide. New York: Aldine de Gruyter.

Dennett, D. C. (1995). Darwin's dangerous idea: Evolution and the meanings of life. New York: Simon \& Schuster.

Eagly, A. H. (1987). Sex Differences in Social Behavior: A Social-Role Interpretation, Hillsdale, NJ: Lawrence Erlbaum.

Eagly, A. H., \& Wood, W. (1999). The origins of sex differences in human behavior: Evolved disposition versus social roles. American Psychologist, 54, 408-423.

Ellis, B. J., Garber, J. (2000). Psychosocial antecedents of variation in girls' pubertal timing: Maternal depression, stepfather presence, and marital and family stress. Child Development, 71, 485-501.

Ellis, B. J., McFadyen-Ketchum, S., Dodge, K. A.; Pettit, G. S.; Bates, J. E. (1999). Quality of early family relationships and individual differences in the timing of pubertal maturation in girls: A longitudinal test of an evolutionary model. Journal of Personality \& Social Psychology, 77, 387-401.

Fausto-Sterling, A. (2000). Beyond difference: Feminism and evolutionary psychology. In H. Rose and S. Rose (Eds.) Alas poor Darwin: Arguments against evolutionary psychology (pp. 209-247). New York: Harmony Books.

Fodor, J. (2000). The mind doesn't work that way: The scope and limits of computational psychology. Cambridge MA: MIT Press. 
Gangestad, S. W., \& Buss, D. M. (1993). Pathogen prevalence and human mate preferences. Ethology and Sociobiology, 14, 89-96.

Gangestad, S. W., Simpson, J. A. (2000). The evolution of human mating: Tradeoffs and strategic pluralism. Behavioral \& Brain Sciences, 23, 573-644.

Gould, S. J. (1979). Mickey Mouse meets Konrad Lorenz. Natural History, 88, 30-36.

Gould, S. J. (1997). "Evolution: The Pleasures of Pluralism" (June 26). The New York Review of Books.

Gould, S. J. (2000). More things in heaven and earth. In H. Rose and S. Rose (Eds.) Alas poor Darwin: Arguments against evolutionary psychology (pp. 101-126). New York: Harmony Books.

Gould, S. \& Lewontin, R. (1979). The spandrels of San Marco and the Panglossian program: A critique of the adaptationist program. Proceedings of the Royal Society of London, 250, 281-288.

Harris, C. R. (2000). Psychophysiological responses to imagined infidelity: The specific innate modular view of jealousy reconsidered. Journal of Personality \& Social Psychology, 78, 1082-1091.

Herrnstein Smith, B. (2000). Sewing up the mind: The claims of evolutionary psychology. In H. Rose and S. Rose (Eds.), Alas poor Darwin: Arguments against evolutionary psychology (pp. 155-172). New York: Harmony Books.

Hill, K. \& Hurtado, A. M. (1996). Ache life history: The ecology and demography of a foraging people. New York: Aldine de Gruyter. 
Hill, E. M., Thomson Ross, L., and Low, B. S. (1997). The role of future unpredictability in human risk-taking. Human Nature, 8, 287-325.

Hirschfeld, L. A., \& Gelman, S. A. (1994). Mapping the mind: Domain specificity in cognition and culture. New York: Cambridge University Press.

Holcomb III, H. R. (1998). Testing evolutionary hypotheses. In C. Crawford \& D. R. Krebs (Eds.) Handbook of evolutionary psychology: Ideas, issues, and applications (pp. 303-334). New Jersey: Lawrence Erlbaum.

Jencks, C. (2000). EP, phone home. In H. Rose and S. Rose (Eds.) Alas poor Darwin: Arguments against evolutionary psychology (pp. 33-54). New York: Harmony Books.

Kanwisher, N. (2000). Domain specificity in face perception. Nature Neuroscience, $3,759-763$.

Karmiloff-Smith, A. (2000). Why babies' brains are not Swiss army knives. In H. Rose \& S. Rose (Eds.), Alas, poor Darwin: Arguments against evolutionary psychology (pp. 173-187). New York: Harmony Books.

Kasser, T. \& Sharma, Y. S. (1999). Reproductive freedom, educational equality, and females' preference for resource-acquisition characteristics in mates. Psychological Science, $10,374-377$.

Ketelaar, T. and Ellis, B. J. (2000). Are evolutionary explanations unfalsifiable? Evolutionary psychology and the Lakatosian philosophy of science. Psychological Inquiry, 11, 1-21. 
Kurzban, R. Tooby, J. and Cosmides, L. (2001). Can race be erased? Coalitional computation and social categorization. Proceedings of the National Academy of Sciences, 98, 15387-15392.

Low, B. S. (1989). Cross-cultural patterns in the training of children: An evolutionary perspective. Journal of Comparative Psychology, 103, 311-319.

Malamuth, N. M. (1998). An evolutionary-based model integrating research on the characteristics of sexually coercive men. In J. Adair, K. Dion, \& D. Belanger, D. (Eds.). Advances in Psychological Science, Vol. 1: Social, Personal, and Cultural Aspects, (pp. 151-184). Hove, England: Psychology Press.

Mithin, S. (1996). The prehistory of the mind: The cognitive origins of art, religion, and science. London: Thames and Hudson.

Nelkin, D. (2000). Less selfish than sacred?: Genes and the religious impulse in evolutionary psychology. In H. Rose and S. Rose (Eds.), Alas poor Darwin: Arguments against evolutionary psychology (pp. 17-32). New York: Harmony Books.

Pedersen, F. A. (1991). Secular trends in human sex ratios: Their influence on individual and family behavior. Human Nature, 2, 271-291.

Pinker, S. (1994). The language instinct. New York: HarperCollins.

Pinker, S. (1998). How the mind works. New York: W. W. Norton \& Co.

Rose, H. (2000). Colonizing the social sciences? In H. Rose \& S. Rose (Eds.) Alas poor Darwin: Arguments against evolutionary psychology (pp. 127-153). New York: Harmony Books. 
Rose, S. (2000). Escaping evolutionary psychology. In H. Rose \& S. Rose (Eds.) Alas poor Darwin: Arguments against evolutionary psychology (pp. 299-320). New York: Harmony Books.

Rose, H., \& Rose, S. (2000). Introduction. In H. Rose \& S. Rose (Eds.) Alas Poor Darwin: Arguments Against Evolutionary Psychology (pp. 1-15). New York: Harmony Books.

Rose, H., \& Rose, S. (2000). Alas poor Darwin: Arguments against evolutionary psychology. New York: Harmony Books.

Shakespeare, T. and Erikson, M. (2000). Different strokes: Beyond biological determinism and social constructionism. In H. Rose \& S. Rose (Eds.), Alas poor Darwin: Arguments against evolutionary psychology (pp. 229-247). New York: Harmony Books.

Sperber, D. (1994). The modularity of thought and the epidemiology of representations. In L. H. Hirschfeld \& S. A. Gelman (Eds.). Mapping the mind: Domain specificity in cognition and culture (pp. 39-67). New York: Cambridge University Press.

Sulloway, F. J. (1996). Born to rebel: Birth order, family dynamics, and creative lives. New York, NY: Pantheon Books.

Symons, D. (1979). The evolution Of human sexuality. New York: Oxford University Press.

Symons, D. (1992). On the use and misuse of Darwinism in the study of human behavior. In J. Barkow, L. Cosmides, \& J. Tooby (Eds.), The Adapted Mind (137-159). New York: Oxford University Press. 
Tooby, J., \& Cosmides, L. (1990). The past explains the present: Emotional adaptations and the structure of ancestral environments. Ethology and Sociobiology, 11, $375-424$.

Tooby, J., \& Cosmides, L. (1992). The Psychological Foundations of Culture. In J. Barkow, L. Cosmides, \& J. Tooby (Eds.), The Adapted Mind (19-136). New York: Oxford University Press. 